\title{
KETIDAKADILAN GENDER PERSPEKTIF HUKUM ISLAM
}

\author{
Oleh : Sippah Chotban \& \\ Azis Kasim \\ aziskasim80@gmail.com
}

Fakultas Syari'ah dan Hukum UIN Alauddin Makassar

\begin{abstract}
The purpose of this research study is to explore the concept of injustice from the perspective of Islamic law. The Indonesian universe has safely become an "open laboratory" for the feminist movement (both individually and structured in the form of a more organized and massive institution) to do what is termed "gender mainstreaming" in all aspects of social, national, and state life. Even though religious life, in relation to Islam, gender with its various theories and currents criticallydeconstructively began to highlight the construction of Islamic law because it "presupposes" that the construction of Islamic law is gender-biased, subordinate, and patriarchic towards women. Thus, this research study is a type of library research (literature research study) using a philosophical-critical exploratory data analysis model, namely an analytical model that conducts an in-depth and critical reading of the focus of the research study.
\end{abstract}

Keywords: Injustice; Gender; Exploitation; Gender-Bias; Gender Mainstreaming

\begin{abstract}
Abstrak
Tujuan kajian penelitian ini adalah untuk mengeksplorasi konsep ketidakadilan perspektif bukum Islam. Pasalnya, belakangan ini jagat Indonesia secaman menjadi "laboratorium terbuka" bagi gerakan femenis (baik perorangan maupun terstruktur dalam bentuk lembaga yang lebih terorganisir dan masif) untuk melakukan apa yang dinama-istilabkan dengan "pengarusutamaan gender" dalam segenap aspek. kehidupan bermasyarakat, berbangsa dan bernegara, babkan kehidupan beragama sekalipun. Dalam kaitannya dengan Islam, gender dengan ragam teori dan alirannya secara kritis-dekontruktif mulai menyoroti konstruksi bukum Islam karena "mengandaikan" babwa konstruksi bukum Islam bias gender, subordinatif dan partiarkis terbadap perempuan. Dengan demikian, kajian penelitian ini merupakan jenis library research (kajian penelitian kepustakaan) dengan menggunakan model analisis datanya bersifat eksploratif filosofis-kritis, yakni sebuah model analisis yang melakukan pembacaan secara mendalam dan kritis terhadap fokus kajian penelitian.
\end{abstract}

Kata Kunci : Ketidakadilan; Gender; Eksploitasi; Bias-Gender; Pengarus-Utamaan 


\section{A. PENDAHULUAN}

Diskursus mengenai ketidakadilan gender kian hari menjadi sesuatu seamakin menarik. Hal ini wajar-wajar saja oleh sebab banyak fakta sosial yang menunjukkan betapa seringnya terjadi ketidakadilan gender. Bahkan acapkali ketidakadilan gender ini menggunakan stempel basah yang bernama logika agama, semacam mencari pembenaran melalui ragam penafsiran dalam memahami rancang-bangun hukum Islam yang mengatur hal ihwal relasi lakilaki dan perempuan dalam hidup dan kehidupan.

Olehnya dalam diskursus selanjutnya tidak jarang ditemukan banyak sekali asumsi-asumsi destruktif negatif yang dialamatkan kepada hukum Islam bahwa hukum Islam dengan konstruksi hukumnya mulai dari ushul al-figh hingga produk fikih malah turut serta melegitimasi dan melanggengkan narasi ketidkadilan gender yang kian hari kian mengkhawatirkan masa depan peradaban manusia, khususnya dalam kaitannya dengan relasi antara laki-laki dan perempuan.

Berdasarkan itu, maka penting kiranya untuk melakukan kajian untuk mendudukkan kembali konsep hukum Islam dalam relasinya dengan ketidakadilan gender secara rasonal dan proporsional mulai dari mengungkapkan kembali konsep ketidakadilan gender dan konsep sebenarnya tentang hukum Islam.

\section{B. LITERATURE REVIEW}

\section{Gender Antara Sex dan Role}

Pemaknaan term gender dalam perbendaharaan literatur pergeseran paradigma (shifting paradigm). Pada awalnya, term gender diartikan dengan jelas sebagai 'jenis kelamin', ${ }^{1}$ suatu istilah yang memiliki makna yang sama dengan seks. ${ }^{2}$ Keduanya digunakan untuk mengidentifikasi sekaligus menjelaskan jenis kelamin antara laki-laki dan perempuan seperti yang lazim dipahami dan dipergunakan kebanyakan orang. Dalam perkembangannya, keduanya mulai dibedakan makna dan penggunaannya. Adalah Robert Stoller orang yang pertama kali memperkenalkan istilah 'gender' untuk memisahkan pencirian manusia yang didasarkan pada pendefenisian yang bersifat sosial budaya dengan pendefenisian yang bersifat biologis. Termasuk orang yang berjasa dalam mengembangkan istilah dan pengertian gender dalam ilmu sosial adalah Ann

${ }^{1}$ John M. Echos, dkk., Kamus Inggris Indonesia (Cet. XXV. Jakarta: PT Gramedia Pustaka Utama, 2003), h. 265.

${ }^{2}$ Kata sex digunakan dan dimaknai sebagai sebuah istilah khusus yang bersifat biologis dalam menjelaskan jenis kelamin laki-laki dan perempuan. Sedangkan kata gender bersifat non biologis dalam menjelaskan perbedaan peran dan fungsi sosial kultural antara laki-laki dan perempuan. Lihat Nasiruddin Umar, Argumentasi Kesetaraan Jender Perspektif al-Qur'an (Cet. II; Jakarta: Paramadina, 2001), h. 35. 
Oakley. Sebagaimana halnya Stoller, Oakley menjadikan gender sebagai istilah untuk mengidentifikasi perbedaan yang bersifat sosial budaya. ${ }^{3}$

Term gender tidak lagi diartikan dengan dan atau sebagai seks: tidak digunakan untuk mengidentifikasi perbedaan yang bersifat biologis antara lakilaki dan perempuan. ${ }^{4}$ Ia digunakan untuk mengidentifikasi perbedaan yang bersifat "sosial budaya" antara laki-laki dan perempuan. Pemaknaan ini sebagaimana dijelaskan dalam Women's Studies Encyclopedia, bahwa gender adalah suatu konsep kultural yang berupaya membuat pembedaan (distinction) dalam hal peran, perilaku, mentalitas dan karakteristik emosional antara laki-laki dan perempuan yang berkembang dalam masyarakat. ${ }^{5}$ Senada dengan itu, H.T. Wilson dalam Sex and Gender mengartikan gender sebagai suatu dasar untuk menentukan perbedaan kontribusi antara laki-laki dan perempuan pada kebudayaan dan kehidupan kolektif yang sebagai akibatnya mereka menjadi lakilaki dan perempuan. ${ }^{6}$ Begitu pula Hilary M. Lips dalam bukunya Sex and Gender: An Introduction mengartikan gender sebagai harapan-harapan budaya terhadap laki-laki dan perempuan. ${ }^{7}$

Pemaknaan serupa juga diutarakan Mansour Fakih bahwa gender sebagai suatu sifat yang melekat pada kaum laki-laki maupun perempuan yang dikonstruksi secara sosial dan kultural. ${ }^{8}$ Menurut Nasaruddin Umar, gender adalah suatu konsep yang digunakan untuk mengidentifikasi perbedaan laki-laki dan perempuan dilihat dari lini sosial-budaya. ${ }^{9}$ Sedangkan menurut Musdah Mulia, gender adalah seperangkat sikap, peran, fungsi dan tanggung jawab yang melekat pada diri laki-laki dan perempuan akibat bentukan budaya atau pengaruh lingkungan masyarakat di mana manusia itu tumbuh dan dibesarkan. ${ }^{10}$

Dengan demikian, gender adalah suatu konsep yang digunakan untuk mengidentifikasi perbedaan laki-laki dan perempuan dari sudut pandang kontruksi sosial budaya. Hal ini berbeda dengan seks yang secara umum digunakan untuk mengidentifikasi perbedaan laki-laki dan perempuan dari

${ }^{3}$ Riant Nugroho, Gender dan Strategi Pengarus-Utamaan di Indonesia (Cet. I; Yogyakarta: Pustaka Pelajar, 2011), h. 3.

${ }^{4}$ Pemahaman dan pembedaan konsep sex dan gender sangat diperlukan dalam melakukan analisis untuk memahami persoalan-persoalan ketidakadilan sosial yang menimpa kaum perempuan. Lihat Mansour Fakih, Analisis Gender dan Transformasi Sosial (Yogyakarta: Pustaka Pelajar, 1996), h. 3.

'Lihat Aidian Husaini, "Kesetaraan Gender: Konsep dan Dampaknya Terhadap Islam," ISLAMIA 2, no. 5 (2012), h. 14.

${ }^{6}$ H.T. Wison, Sex and Gender, Making Cultural Sense of Civilization (Lieden: E.J. Brill, 1989), h. 2.

${ }^{7}$ Riant Nugroho, Gender dan Strategi Pengarus-Utamaannya di Indonesia, h. 5.

${ }^{8}$ Mansour Fakih, Analisis Gender dan Transformasi Sosial, h. 8.

${ }^{9}$ Nasaruddin Umar, Argumen Kesetaraan Gender Perspektif Al-Qur'an, h. 35.

${ }^{10}$ Musdah Mulia, Muslimah Sejati: Menempuh Jalan Islam Meraih Ridha Ilahi (Cet. I; Bandung: Penerbit Marja, 2011), h. 65. 
aspek anatomi biologi. Term seks lebih banyak berkonsentrasi pada aspek biologis seseorang yang meliputi perbedaan komposisi kimia dan hormon dalam tubuh, anatomi fisik, reproduksi dan karakteristik biologis lainnya. Sementara gender lebih banyak berkonsentrasi pada aspek sosial, budaya, psikologis dan aspek-aspek non-biologis lainnya. Studi gender lebih menekankan pada perkembangan maskulinitas (masculinity/rujuliyah) atau feminitas (feminity/nisa'iyah). Sedangkan studi sex lebih menekankan perkembangan aspek biologis dan komposisi kimia dalam tubuh laki-laki (maleness/zhukurah) dan perempuan (femaleness/unutsah). ${ }^{11}$

\section{Teori Gender}

Persoalan yang segera muncul setelah menjelaskan perbedaan gender dan seks adalah apakah proses pembentukan gender laki-laki dan perempuan mempunyai hubungan dengan struktur biologis dan kodrati ataukah murni dikarenakan konstruksi sosial budaya. Pertanyaan ini pada akhirnya melahirkan beberapa asumsi teoretis, di antaranya yang paling akrab dikenal dalam diskursus gender, yaitu teori nurture dan teori nature.

\section{a. Teori Nurture}

Inti teori nurture mengandaikan bahwa perbedaan gender (gender differences) atau lebih spesifik lagi peran gender (gender role) yang mencakup sifat meskulin dan feminim bukan ditentukan oleh dan berdasarkan perbedaan biologis, melainkan karena konstruksi sosial dan budaya yang melingkupi dinamika kehidupannnya. Artinya, perbedaan gender tidak ada kaitannya dengan perbedaan biologis. Bentuk perbedaan gender dalam teori ini dianggap sesuatu yang alami, karena sering terulang, sehingga harus diterima. Teori ini memungkinkan adanya pertukaran peran gender antara laki-laki dan perempuan. Hal demikian dikarenakan faktor yang menjadi latar belakang perbedaan gender sepenuhnya bersifat konstruksi sosial dan budaya. ${ }^{12}$

\section{b. Teori Nature}

Inti teori nature mengandaikan perbedaan gender laki-laki dan perempuan merupakan konstruksi jenis kelamin biologis. Hal ini berbeda dengan teori nature yang mengandaikan jenis kelamin sosial dan budaya sebagai satu-satunya sebab dan faktor dalam pembentukan perbedaan gender. Pengandaian teori nature tersebut berangkat dari fakta empiris seputar perbedaan gender laki-laki dan perempuan. Di mana banyak sekali perbedaan gender dikonstruksi berdasarkan pada perbedaan jenis kelamin. Sebut saja dalam hal ini peran gender perempuan (baca: ibu) sebagai pengasuh anak. Peran ibu sebagai pengasuh anak tidak bisa dipisahkan dari jenis kelamin biologis dan sesuatu yang bersifat kodrati pada

${ }^{11}$ Lihat Nasaruddin Umar, Argumen Kesetaraan Gender Perspektif Al-Qur'an, h. 35.

${ }^{12}$ Nila Sastrawaty, Laki-laki dan Perempuan Identitas yang Berbeda: Analisis Gender dan Politik Perspektif Post-Feminisme (Cet. I; Makassar: Alauddin University Press, 2013), h. 44. 
perempuan, berupa hamil, melahirkan dan menyusuhi anaknya (dengan payu darahnya). ${ }^{13}$

\section{Aliran Gender}

Kelahiran aliran feminisme tidak terlepas dari bentuk ketidakadilan gender yang terjadi dan menimpa kaum perempuan. Setiap aliran feminisme mempunyai fokus masing-masing dalam mengidentifikasi ketidakadilan gender: semua berbeda dalam melihat latar belakang yang menyebabkan ketidakadilan gender. Namun, tetap terdapat homogenitas pemikiran di antaranya. Yakni kesatuan pemikiran dalam menggugat dan mempertanyakan hubungan dominasi dan subordinasi antara laki-laki dan perempuan: menggugat struktur interaksi kekuasaan di antara laki-laki dan perempuan. ${ }^{14}$ Persoalan ketidakadilan gender yang menimpa dan dialami kaum perempuan menjadi faktor yang dominan mengilhami lahir dan berkembangnya gerakan feminisme, di Barat maupun di Timur.

a. Aliran Liberal

Aliran feminisme liberal berakar pada tradisi berpikir liberal Barat yang berpilar pada rasionalisme, liberalisme, dan individualisme. Juga menganut pemikiran nihilisme dan relativisme. ${ }^{15}$ Dengan pilar liberalisme, aliran ini membangun dasar pemikiran bahwa semua manusia, laki-laki dan perempuan, diciptakan seimbang dan serasi dan mestinya tidak terjadi penindasan antara satu dengan lainnya. ${ }^{16}$ Dasar pemikiran demikian terinspirasi dari doktrin John Locke tentang natural right (hak asasi manusia), bahwa setiap manusia mempunyai hak asasi, yaitu hak untuk hidup, mendapatkan kebebasan dan hak untuk mencari kebahagian. ${ }^{17}$ Atau dalam istilah Nasiruddin Umar, mempunyai kekhususankekhususan. ${ }^{18}$

b. Aliran Marxis-Sosialis

Aliran ini mengandaikan bahwa kaum perempuan kedudukannya identik dengan kaum proletar pada masyarakat kapitalisme Barat. Mereka dalam teorinya mempersalahkan konsep kepemilikan pribadi, dan menganalogikan perkawinan sebagai lembaga yang melegitimasikan pria memiliki istri secara

${ }_{13}^{13}$ Peran gender demikian bukan berarti tidak bisa dilakukan oleh seorang laki-laki (baca: suami). Namun, di sini hanya bermaksud menjelaskan spesifikasi teori nature dalam kehidupan praktis.

${ }^{14}$ Lihat Riant Nugroho, Gender dan Strategi Pengarus-utamaannya di Indonesia, h. 62.

${ }^{15}$ Sandi Suwardi Hasan, Pengantar Cultural Studies: Sejarah, Pendekatan Konseprual dan Isu Menuju Studi Budaya Kapitalisme Lanjut, h. 238.

${ }^{16}$ Nasaruddin Umar, Argumen Kesetaraan Gender Perspektif Al-Qur'an, h. 64.

${ }^{17}$ Lihat Riant Nugroho, Gender dan Strategi Pengarus-utamaannya di Indonesia, h. 63.

${ }^{18}$ Nasaruddin Umar, Argumen Kesetaraan Gender Perspektif Al-Qur'an, h. 64. 
pribadi. Gejala ini dipandang oleh kedua tokoh ini merupakan bentuk penindasan terhadap perempuan. ${ }^{19}$

c. Aliran Radikal

Aliran ini muncul di permulaan abad ke 19 dengan mengangkat isu besar, menggugat semua lembaga yang dianggap merugikan perempuan seperti lembaga patriarki yang dinilai merugikan perempuan, karena term ini jelas-jelas mengungtungkan laki-laki. Lebih dari itu, di anatar kaum feminis radikal ada yang lebih ekstrem, tidak hanya menuntut kesamaan hak dengan laki-laki tetapi juga persamaan "seks", dalam arti kepuasan seksual juga bisa diperoleh dari sesama perempuan sehingga mentolerir praktek lesbian. ${ }^{20}$

\section{d. Teologi Feminis}

Teologi feminisme ini berkembang pada berbagai agama seperti Kristen, Yahudi, dan Islam. Menurut para feminis, agama-agama tersebut sering ditafsirkan dengan ideologi patriarki dan menyudutkan perempuan. Isu-isu yang sering dipermasalahkan adalah tentang penciptaan Adam dan Hawa, dan kepemimpinan perempuan dalam agama. Misalnya, menolak penafsiran bahwa Hawa diciptakan dari tulang rusuk Adam. Teologis feminis dalam Islam juga menolak ayat al-Qur'an yang secara eksplisit menyatakan istri diciptakan dari diri suaminya. ${ }^{21}$ Juga menolak anggapan bahwa perempuan kerjanya hanya di rumah dan ketika menjadi pemimpin, maka suatu negara dan peradaban akan hancur binasa.

e. Feminis Muslim

Gerakan feminisme yang mengusung pembebasan perempuan dari ketertindasan dan mengeluarkan perempuan dari hegemoni budaya patriarki, mau tidak mau memasuki ranah kritik teologis. Dengan cepat menyebar ke berbagai agama di dunia. ${ }^{22}$ Upaya gender memasuki wilayah agama membuat persoalan menjadi tambah kompleks, karena pada umumnya, ketidakadilan gender merupakan masalah agama, sehingga tradisi dan khazanah keagamaan dipertanyakan ulang. Isu ketidakadilan gender yang tadinya hanya dilakukan oleh kaum liberalisme Kristen, namun secara perlahan tapi pasti ikut mempengaruhi Islam. ${ }^{23}$

Hal demikian menyebabkan feminis muslim yang terlibat dalam wacana kesetaraan gender melakukan perombakan terhadap konsep-konsep Islam

${ }^{19}$ Lihat Riant Nugroho, Gender dan Strategi Pengarus-utamaannya di Indonesua, h. 69. Lihat Ratna Megawangi, Membiarkan Berbeda? (Bandung: Mizan, 1999), h. 11.

${ }^{20 N a s a r u d d i n ~ U m a r, ~ A r g u m e n ~ K e s e t a r a a n ~ G e n d e r ~ P e r s p e k t i f ~ A l-Q u r ' a n, ~ h . ~ 66-67 . ~ L e s b i a n ~}$ adalah wanita yang memuaskan birahinya dengan sesama jenisnya; wanita homoseks. Dendy Sugono, Kamus Bahasa Indonesia (Jakarta: Pusat Bahasa, 2008), h. 919.

${ }^{21}$ Ratna Megawangi, "Menimbang Teori Feminisme Masa Kini dan Mendatang serta Kaitannya dengan Pemikiran Keislaman", h. 227.

22Kadarusman, Agama, Relasi Gender dan Feminisme (Yogyakarta: Kreasi Wacana, 2005), h. 63.

${ }^{23}$ Mohammad Muslih, Bangunan Wacana Gender (Ponorogo: CIOS, 2007), h. 16. 
tentang perempuan, dan kemudian disesuaikan dengan nilai-nilai modern yang berlaku sekarang. Dalam perspektif feminis muslim, sangat banyak hukum yang berlaku dalam masyarakat muslim merupakan hasil konstruksi kaum laki-laki. Sehingga perlu membuat hukum tandingan, yang sesuai dengan perspektif dan kepentingan perempuan. ${ }^{24}$

Keberadaan feminis muslim ${ }^{25}$ sudah ada sejalan dengan berkembangnya paham teologi pembebasan (feminis theologi). Landasan filosofisnya pun bisa dikatakan sama dengan teologi feminis dan aliran feminis lainnya, yaitu menjadikan isu ketidakadilan gender sebagai basis gerakannya. Dengan isu tersebut, semua narasi ketidakadilan gender dipersoalan. Ketidakadilan gender dianggap berawal mula/disebabkan karena faktor penafsiran yang bias gender. Sehingga, fokus gerakan feminis muslim adalah pada penafsiran keagamaan yang bersifat patriarki dan misoginis terhadap perempuan. Implikasinya, semua produk hukum yang dianggap melanggengkan dominasi dan hegomoni nalar patriarki dan misoginis ditinjau kembali dengan semangat transformasi geender equality.

\section{METODE}

Jenis penelitian ini adalah penelitian kualitatif deskripstif atau penelitian kepustakaan, yakni mendeskripsikan hal-hal yang terkait gender dan bias gender. Data-data yang terkumpul berupa data sekunder, oleh karena itu dibutuhkan analisis yang kuat untuk melakukan kalibrasi terhadap berbagai informasi yang ditemukan dari sumber sekunder tersebut. Analisis induktif, deduktif menjadi tumpuan dalam melakukan analisis data yang terkumpul.

Secara objektif, tulisan ini terfokus pada gender, bias gender dalam konteks kehidupan, sehingga kami menamakannya sebagai laboratorium hidup dalam masyarakat. Hukum Islam kemudian menjadi landasan ideology untuk mengamati pola dan perilaku terhadap gender dengan menguji kesesuain dan perbedaannya dengan teori hukum Islam.

\section{RESHULTS \& DISCATION}

\section{Konsep Ketidak-adilan Gender}

Dengan memahami hakikat substantif gender nampak terlihat bahwa di sana ada upaya yang cukup serius, sistematis dan massif dalam memperjuangwujudkan tatanan kehidupan "laki-laki" dan terlebih khusus "perempuan" yang jauh dari berbagai bentuk manifestasi ketidakadilan gender. Upaya ini dalam kajian ini disebut-istilahkan dengan "genderisasi", yaitu sebuah gerakan

${ }^{24}$ Adian Husaini, "Kajian Islam Historis dan Aplikasinya dalam Studi Gender", ISLAMIA 4, no. 1 (2009), h. 20.

${ }^{25}$ Dikatakan feminis muslim, karena orang-orang yang terkenal aktif sebagai pegiat kajian dan pengarusutamaan gender menyandang identitas sebagai orang yang beragama Islam. 
emansipasi, feminisme dan atau pengarusutamaan gender yang lagi marak dikempanyekan bahkan diperjuang-wujudkan dalam berbagai aspek dan lini kehidupan bermasyarakat, berbangsa dan bernegara, bahkan beragama sekalipun.

Secara sederhana, ketidakadilan gender adalah istilah yang biasa digunakan untuk menunjukkan perlakuaan yang berbeda terhadap gender (gender differences). Karenanya, ketidakadilan gender lebih merupakan ideologi, sistem dan struktur di mana baik kaum laki-laki dan perempuan menjadi korban dari sistem tersebut. Bentuk manifestasinya terbilang cukup variatif mulai dari aspek klasifikasinya maupun konten penjelasannya. Ada yang masih bersifat umum, belum menyentuh secara khusus masalah ideologi dan dogma agama beserta pemahaman dan produk hukum yang mengatur pola relasi gender antara laki-laki dan perempuan. Sementara itu, kaum feminisme juga mengkategorikan "aspek agama" sebagai penyebab (lain) dari ketidakadilan gender. Sebab, agama diandaikan masih terdapat pemikiran berikut produknya dalam bentuk ketentuan hukum yang begitu jelas membedakan peran gender antara laki-laki dan perempuan. Hal ini wajar-wajar saja oleh sebab masing-masing memiliki latar intelektual yang berbeda dalam melakukan "pembacaan" terhadap "bentuk ketidakadilan gender" dalam relasinya dengan narasi keagamaan dan lainnya.

Menurut Mansour Fakih, ${ }^{26}$ dalam Islam ada beberapa tema pokok yang berkaitan dengan hubungan antara laki-laki dan perempuan yang merupakan bentuk ketidakadilan gender, karena memang bukanlah kodrat Tuhan. Pertama, subordinasi kaum muslimat. Subordinasi terhadap kaum muslimat yang dimaksud berangkat dari penafsiran terhadap ayat 34 surat al-Nisā' tentang posisi dan peran muslimat dalam rumah tangga. ${ }^{27}$ Penafsiran yang mengatakan laki-laki adalah pemimpin atas perempuan (dalam rumah tangga) dianggap subordinatif terhadap muslimat terlebih-lebih lagi jika kepemimpinan laki-laki menimbulkan ketidakadilan gender, misalnya dalam bentuk diskriminasi kepemimpinan, marginalisasi ekonomi, kekerasan dan beban kerja. ${ }^{28}$

Kedua, kekerasan (violence) terhadap kaum muslimat berupa pemukulan dan serang non-fisik yang terjadi dalam rumah tangga (domestic violence). Termasuk kekerasaan atau penyiksaan terhadap anak (child abuse). Juga

${ }^{26}$ Lihat Mansoer Fakih, "Posisi Kaum Perempuan dalam Islam: Tinjauan dari Aanalisis Gender," dalam Membincang Feminisme: Diskursus Gender Perspektif Islam, h. 53-82. Lihat dan bandingkan Zaituna Subhan, Rekonstruksi Pemahaman Gender dalam Islam: Agenda Sosio-Kultural dan Politik Peran Perempuan (Jakarta: El-Kahfi, 2002), h. 58. Lihat pula Mansou Fakih, Menggeser Konsepsi Gender dan Tranformasi Sosial, h. 14-70.

${ }^{27}$ lihat KH. Husein Muhammad, Fiqh Perempuan: Refleksi Kiai atas Wacana Agama dan Gender (Cet. VI; Yogyakarta: LKiS, 2012), h. 10-13. Lihat pula Sufyan A. P. Kau dan Zulkarnain Sulaiman, Fikih Kontemporer, h. 145-146.

${ }^{28}$ Lihat Mansoer Fakih, "Posisi Kaum Perempuan dalam Islam: Tinjauan dari Aanalisis Gender," dalam Membincang Feminisme: Diskursus Gender Perspektif Islam, h. 53-55. 
pemukulan terhadap istri oleh suami, khususnya dalam kasus nusyuz.. ${ }^{29}$ Dasar argumentasi pemukulan terhadap istri oleh suami dalam kasus nusyuz adalah QS al-Nisā', 4:34 dengan alasan 'istri memberontak'. Dengan ayat ini pula secara luas dikalangan umat Islam lahir keyakinan, bahwa suami berhak memukul istrinya. Padahal dalam tradisi terdapat indikasi Nabi pun menganggap pemukulan terhadap istri sebagai suatu kekerasan yang perlu dihentikan. ${ }^{30}$

Ketiga, stereotype (pelabelan negatif) kaum muslimat. Dalam Islam, banyak sekali ketidakadilan terhadap muslimat yang bersumber pada stereotype yang berdasarkan keyakinan keagamaan. Misalnya saja muslimat dianggap penyebab fitnah syahwat bagi laki-laki ketika ia bersolek dalam rangka memancing perhatian lawan jenisnya. Sehingga setiap kasus kekerasan seksual atau pelecehan seksual selalu dikaitkan dengan hal ini. Akibatnya kecenderungan masyarakat lebih menyalahkan korbannya.

Keempat, marginalisasi kaum muslimat. Terdapat banyak proses dalam masyarakat dan negara yang membuat miskin laki-laki maupun perempuan, seperti misalnya proses eksploitasi. Proses pemiskinan terhadap perempuan pun bersumber dari keyakinan atau tafsiran keagamaan. Misalnya saja hukum waris dalam fikih yang menetapkan porsi waris perempuan setengah dari anak lakilaki. Pola pembagian warisan demikian dianggap bias gender: hanya menguntungkan laki-laki dan merugikan perempuan. Dalam konteks masyarakat modern dewasa ini model penafsiran keagamaan semacam itu bukan saja bersifat bias gender, tapi justru mengakibatkan pemiskinan kepada kaum muslimat. Karenanya dituntut melakukan tranformasi penafsiran terhadap ayat 11 QS alNisā'.

Kelima, Beban kerja (burden) kaum muslimat. Bentuk ketidakadilan gender ini mendapat legitimasi tafsiran keagamaan terhadap ayat 233 QS al-Baqarah. Dengan ayat ini, peran gender dalam hal mencari nafkah merupakan kewajiban normatif laki-laki, sedangkan perempuan hanya berkewajiban mengurusi peran domestik. Penafsiran demikian semakin parah jika diperkuat dengan anggapan bahwa kaum perempuan itu bersifat memelihara dan rajin, serta tidak cocok untuk menjadi kepala rumah tangga. Anggapan ini pada akhirnya membawah akibat bahwa semua pekerjaan domestik rumah tangga menjadi tanggung jawab

\footnotetext{
${ }^{29} \mathrm{Nusyuz}$ berarti 'menentang', terambil dari kata al-nasyaz yang artinya bagian bumi yang tinggi. Sementara secara terminologi fikih nusyuz beratti tidak tunduk dan taat kepada suami. Lihat Abdillah Mustari, Reinterpretasi Konsep-Konsep Hukum Perkawinan Islam (Cet. I; Makassar: Alauddin University Press, 2011), h. 196. Lihat Amiur Nuruddin dan Azhari Akmal Tarigan, Hukum Perdata Islam di Indonesia: Studi Kritis Perkembangan Hukum Islam dari Fikih, UU No 1/1974 sampai KHI (Cet. IV; Jakarta: Prenadamedia Group, 2012), h. 209-211. Lihat M. Thahir Maloko, Dinamika Hukum dalam Perkawinan (Cet. I; Makassar: Alauddin University Press, 2012), h. 179-186. $\mathrm{L}$

${ }^{30}$ Lihat Mansoer Fakih, "Posisi Kaum Perempuan dalam Islam: Tinjauan dari Aanalisis Gender," dalam Membincang Feminisme: Diskursus Gender Perspektif Islam, h. 55-58.
} 
perempuan, ${ }^{31}$ sementara bagi kaum laki-laki tidak ada kewajiban dan tanggung jawab terkait dengan pekerjaan domestik. Pola pemahaman ini dianggap berperan dalam membatasi pekerjaan perempuan dalam rana domestik dan lakilaki dalam rana publik.

Berbagai bentuk manifestasi ketidakadilan gender tersebut disebabkan oleh beberapa faktor. Pertama, adanya arogansi laki-laki yang sama sekali tidak memberikan kesempatan kepada perempuan untuk berkembang secara maksimal. Kedua, adanya anggapan kalau laki-laki disepakati sebagai pencari nafkah utama dalam keluarga. Ketiga, adanya kultur yang selalu memenangkan laki-laki telah mengakar di masyarakat. Keempat, norma hukum dan kebijakan politik yang diskriminatif. Kelima, perempuan sangat rawan pemerkosaan dan bila ini terjadi akan merusak citra dan norma baik di keluarga dan masyarakat, sehingga perempuan harus dipenjarakan dalam tugas domestik saja. ${ }^{32}$

Menurut Mohammad Yasir Alimi dalam Sufyan A. P. Kau dan Zulkarnain Sulaiman, ada dua faktor yang menyebabkan terjadinya ketidakadilan gender (gender inequality). Pertama, faktor budaya male chauvinistic, yaitu suatu budaya yang menganggap laki-laki sebagai makhluk yang kuat dan superior. Pandangan dan maupun kecenderungan ini bisa terjadi karena adanya pengaruh budaya/kebudayaan lokal. Kedua, faktor hukum, baik itu isi hukum (konten of law), budaya hukum (culture of law) maupun proses pembuatan dan penegakan hukum (structure of law). Hukum yang dibuat oleh negara seringkali diskriminatif terhadap perempuan, karena pembuat hukum tidak peka terhadap kebutuhan spesifik perempuan (baca: masalah gender), begitu pula halnya aparat penegak hukum. Itulah lingkaran konspirasi budaya (agama) dan sistem politik yang mengingkari hak-hak perempuan. ${ }^{33}$

\section{Perspektif Hukum Islam Tentang Ketidakadilan Gender}

Konsep dan fonemena ketidakadilan gender yang dikemukan sebelumnya di atas dalam perkembangan selanjutnya mau tidak menuntut adanya pola pembacaan baru dengan berbagai perspektif. Setidaknya pola pembacaan baru diharapkan dapat menghadirkan perspektif baru dalam melihat dan menyelesaikan persoalan demi persoalan yang bertalian dengan ketidakadilan gender. Dalam pelbagai diskursus, banyak ragam pola pembacaan yang dihadirkan. Salah satu di antaranya adalah pola pembacaan baru berdasarkan perspektif hukum Islam. Meskipun dalam konteks ini tidak dinafikan juga bahwa hukum Islam acapkali diasumsikan turut serta melanggengkan ketidakadilan gender. Namun, pada sesungguhnya asumsi demikian sangat terulang pada

${ }^{31}$ Lihat Mansoer Fakih, "Posisi Kaum Perempuan dalam Islam: Tinjauan dari Aanalisis Gender," dalam Membincang Feminisme: Diskursus Gender Perspektif Islam, h. 58-62.

${ }^{32}$ Mansou Fakih, Menggeser Konsepsi Gender dan Tranformasi Sosial, h. 60-70.

${ }^{33}$ Sufyan A. P. Kau dan Zulkarnain Sulaiman, Fikih Kontemporer: Isu-Isu Gender Menghadirkan Teks Tandingan, h. 9-10. 
konstruksi wolrdview yang digunakan dalam melakukan pembacaan hukum Islam dalam relasinya dengan persoalan ketidkadilan gender.

Terlepas dari itu, setidaknya ada beberapa perspektif hukum Islam yang dapat digunakan untuk melakukan pembacaan baru atas persoalan ketidakadilan gender. Perspektif ini sejatinya tidak begitu asing lagi dalam diskursus keilmuan hukum Islam (kontemporer), karena terbilang sesuatu yang menjadi esensi dari eksistensi keberadaan (hukum) Islam (itu sendiri). Bahkan tidak berlebihan kalau dikatakan ia seumuran dengan (hukum) Islam; sesuatu yang menjadi identitas ontologis dan epistemologis (hukum) Islam, semua persoalan hukum Islam dikonstruksi berdasarkannya. Perspektif ini tidak hanya menjawab persoalan ketidakadilan gender, tetapi sekaligus juga menjawab asumsi (untuk tidak mengatakan "tuduhan" destruktif negatif) bahwa konstruksi hukum Islam juga membawa spirit ketidakadilan gender.

\section{Perspektif Tauhid}

Tauhid merupakan salah satu prinsip hukum Islam yang paling asasi, ia bukan saja menjiwai agama secara umum, tetapi juga menjiwai nafas hukum Islam yang notabene merupakan salah satu aspek penting dari agama itu sendiri. ${ }^{34}$ Secara bahasa, tauhid yang dikenal sebagai bahasa khas Indonesia merupakan kata yang berasal dari bahasa Arab, yaitu mashdar (kata benda) dari

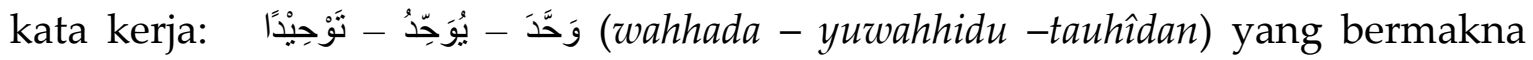
membuat sesuatu menjadi satu. ${ }^{35}$ Dalam makna generiknya juga digunakan untuk arti "mempersatukan" hal-hal yang terserak-serak atau terpecahpecah, misalnya penggunaan dalam bahasa Arab tauhid al-quwwah yang berarti "mempersatukan segenap kekuatan. Sedangkan secara terminologi, tauhid bermakna Mengesakan Allah dengan sesuatu yang khusus bagi-Nya. Baik itu dalam hal rububiyah, uluhiyah maupun nama-nama dan sifatsifat-Nya. ${ }^{36}$

Banyak ayat al-Qur'an begitu pula hadis nabi Muhammad saw. yang menjelaskan tentang kedudukan tauhid dalam agama, juga dalam kaitannya dengan hukum Islam. Narasi filosofis tauhid dalam konteks hukum Islam mengandaikan bahwa umat Islam adalah satu kesatuan dalam perbedaan peran dan tanggung jawab. Semuanya diorientasikan kepada proses penghambaan diri

${ }^{34}$ Dalam klasifikasinya, agama dibedakan menjadi tiga bagian. Pertama; bagian aqidah/tauhid/i'tiqadiyah, yaitu bagian agama yang mengatur-membicarakan hal ihwal tentang struktur keyakinan umat manusia. Kedua; bagian syariah, yaitu bagian agama yang mengaturmembicarakan hal ihwal tentang struktur hukum antar seorang manusia dengan Allah, manusia dengan sesama manusia dan manusia dengan benda dan lainnya. Ketiga; bagian akhlak, yaitu bagian agama yang mengatur-membicarakan hal ihwal tentang tingka laku terhadap Allah dan sesama manusia.

${ }^{35}$ Lihat Muhammad bin Mukrim bin Ali Abu al-Fadhl Jamaluddin Ibnu Manzhur al-Anshari ar-Ruwaifi'i al-Afriqi, Lisân al-'Arab (Beirut: Dâr Lisân al-'Arab, t.t.t.), h. 888.

${ }^{36}$ Lihat Ibn 'Utsaimîn, Al-Qaul al-Mufìd 'Alâ al-Kitâb al-Tauhîd (Riyadh: Dâr Ibn al-Jauzî, 1424), h. 8. 
kepada Allah. Perbedaan demi perbedaan yang dimiliki oleh laki-laki dan perempuan dalam konstruksi hukum Islam tidak berkonotasi bahwa salah satu di antaranya yang lebih mulia dari lainnya sebagaimana yang diasumsikan selama ini oleh berbagai kalangan. Konsep tauhid dalam prinsip hukum Islam menghapus semua manifestasi ketidakadilan gender. Seperti halnya kesyirikan di mana keberadaan Islam dengan konsep tauhidnya menghapus dan menolak semua bentuk manifestasi kesyirikan. Bahkan kesyirikan tergolong sebagai bagian dari kezaliman yang paing zalim. Begitu pula ketidakadilan gender bisa terkategorikan sebagai bagian dari ketidakadilan yang paling tidak adil yang dialamatkan kepada makhluk yang bernama perempuan maupun laki-laki. Tentu hukum Islam yang tidak terlepas dari prinsip dan spirit dasar tauhid juga tidak sama sekali menginginkan adanya ketidakadilan gender dalam konstruksi hukum.

\section{Perspektif Keadilan dan Kesetaraan}

Selain tauhid, keadilan dan kesetaraan juga merupakan prinsip penting dalam hukum Islam. Kata 'adl adalah bentuk mashdar dari kata kerja 'adala ya'dilu - 'adlān - 'udūlān - wa 'adālatan (عدل - يعدل - عدلا - عدو لا - وعدالة). Kata kerja ini berakar pada huruf-huruf 'ain, dal, dan lam, yang makna pokoknya adalah alistiwa' dan al-i'waj. Rangkaian huruf-huruf tersebut mengandung makna yang bertolak belakang, yakni 'lurus' atau 'sama' dan 'bengkok' atau 'berbeda'. Dari makna pertama, kata 'adl berarti 'menetapkan hukum dengan benar'. Seorang yang 'adl berjalan lurus dan sikapnya selalu menggunakan ukuran yang sama, bukan ukuran ganda. 'Persamaan' itulah merupakan makna asal kata 'adl, yang menjadikan pelakunya 'tidak berpihak' kepada salah seorang yang berselisih, dan pada dasarnya pula seorang yang 'adl 'berpihak kepada yang benar', karena baik yang benar maupun salah sama-sama memperoleh haknya. Dengan demikian, ia melakukan sesuatu yang patut dan tidak sewenang-wenang. ${ }^{38}$

Kata adil dalam berbagai derivasinya dalam al-Qur'an terulang kurang lebih dua puluh delapan kali. Pertama, adil dalam arti 'sama' atau tidak memihak serta tidak berat sebelah. Makna ini diungkapkan beberapa ayat, di antaranya dalam QS al-Nisā'/4: 58 yang bermakna persamaan dalam soal hak. Keadilan itu bersifat mutlak yang berarti meliputi keadilan yang menyeluruh di antara semua manusia, bukan keadilan di antara sesama kaum muslimin dan terhadap ahli kitab saja. Keadilan merupakan hak setiap manusia mukmin ataupun kafir, teman ataupun lawan, orang berkulit putih ataupun berkulit hitam dan orang arab ataupun orang ajam (non arab). ${ }^{39}$

37Muhammad ibn Mukrim ibn 'Alī Abu al-Faḍl Jāmal al-Dīn ibn Manẓūr al-Anșārī, Lisan al'Arab, vol. IV (t.t: Dar al-Ma'arif, 1979), h. 2838.

${ }^{38}$ Muchlis M. Hanafi, dkk., Hukum, Keadilan dan Hak Asasi Manusia: Tafsir al-Qur'an Tematik (Jakarta: Lajnah Pentahshihan Mushaf al-Qur' an, 2010), h. 2-3.

${ }^{39}$ Sayyid Quțub Ibrāhīm Ḥusa'in al-Syāżalī, Fì Zilāl al-Qur ān, Jilid II (Cet. XVII. Qairoh: Dār al-Syuruq, 1412), h. 690. 
Selanjutnya dalam QS an-Nisā'/4:135, frase keadilan bermakna dengan frase al-qist yang berarti 'kewajaran', 'keadilan', 'pembagian yang adil'. Dalam QS al-Anbiyā' ayat 47 kata al-qist dilawankan dengan kezaliman. ${ }^{40}$ Maksudnya adalah qișt bermakna berbuat dan bersikap yang adil dan menjauhkan sikap ketidakadilan dalam bersikap karena itu merupakan bagian dari kezaliman dan kezaliman memiliki dampak yang besar dalam hidup terlebih lagi diakhirat kelak. $^{41}$

Kedua, adil dalam arti "seimbang". Keadilan yang dimaksudkan adalah kesesuaian. Dalam artian bahwa kesesuaian dan keseimbangan dalam lingkaran perbedaan, tidak mengharuskan persamaan kadar yang besar dan kecilnya, akan tetapi lebih ditentukan oleh fungsi yang diharapkan darinya. Pengertian frase keadilan ini terdapat dalam QS al-Infițār/82:6-7.

Keadilan dalam hukum Islam adalah sesuatu yang berimbang, tidak mesti selalu dalam pengertian sama berat (fifti-fifti), tetapi dalam pengertian harmonisasi antara bagian-bagiannya sehingga membentuk satu kesatuan yang harmonis. Keadilan tidak harus bermakna sama persis dan persis sama atau sama berat dan berat sama. Dengan demikian, perbedaan peran gender (differences gender of role) antara laki-laki dan perempuan dalam konteks yang demikian bukanlah suatu ketidakadilan, selama tidak melahirkan subordinasi, marginalisasi dan bentuk-bentuk manifestasi ketidakadilan gender.

Dalam perspektif keadilan dan kesetaraan ini, hukum Islam merupakan hukum yang adil dan mengedepankan keseimbangan dalam pembagian peran dan tanggungjawab antara laki-laki dan perempuan. Perbedaan peran dan tanggungjawab antara laki-laki dan perempuan dalam konstruksi hukum Islam bukan sebagai bentuk ketidakadilan gender. Karena itu, dalam perspektif ini pula konsep mengenai ketidakadilan gender kiranya perlu ditinjau kembali. Perbedaan peran dan tanggungjawab laki-laki dan perempuan tidak bisa dilihat sebagai bagian dari simbol yang menggambarkan sekaligus melanggengkan ketidakadilan gender. Ini bukan berarti bahwa konstruksi hukum Islam menginginkan adanya diskriminasi dalam berbagai bentuknya seperti yang dikemukan para ahli sebelumnya di atas.kekerasaa, penghinaan, pelecehaan dan lainnya bukan saja tidak dibenarkan oleh hukum Islam ketika dialamatkan kepada makhluk yang bernama perempuan, tetapi juga untuk laki-laki. Artinya hukum Islam dengan konsep keadilan dan kesetaraan tidak menghendaki sama sekali adanya ketidkadilan gender. Namun, menganggap perbedaan pembagian peran dan tanggungjawab antara laki-laki dan perempuan sebagai bagian dari ketidakadilan gender pun sama sekali tidak dibenarkan oleh hukum Islam.

${ }^{40}$ Rifyal Ka'bah, Politik dan Hukum dalam Alquran (Khairul Bayan: Jakarta, 2005), h. 83.

${ }^{41}$ Abi al-Ḥusa'in Aḥmad ibn Fāris ibn Zakariyā, Mu'jam Muqāyis fì al-Lugah, h. 86. 


\section{E. KESIMPULAN}

Hukum Islam dalam berbagai bentuknya mengnadung prinsip dan spirit dasar yang mengedepankan nilai-nilai keadilan dan kesetaraan. Islam sama sekali tidak membenarkan sedikit pun tindakan ketidakadilan, apa pun itu, terlebih ketidakadilan gender. Bersamaan dengan Islam juga tidak membenarkan ada generalisasi pemahaman bahwa perbedaan peran antara laki-laki dan perempuan merupakan simbol bahkan bagian yang tidak dari ketidakadilan gender.

Karena betapa pentingnya kajian seputar konsep hukum Islam dan ketidakadilan gender, maka kajian-kajian serupa dalam pelbagai bentuknya hendaknya terus dilakukan untuk menjawab persoalan-persoalan baru yang muncul dalam kaitannya dengan relasi laki-laki dan perempuan.

\section{DAFTAR PUSTAKA}

Abdillah Mustari, Reinterpretasi Konsep-Konsep Hukum Perkawinan Islam Cet. I; Makassar: Alauddin University Press, 2011

Engineer, Asghar Ali. The Right of Women in Islam. India: ST Martin's Press, 1996.

Erwin, Muhammad. Filsafat Hukum: Refleksi Kritis Terhadap Huku,Edisi. I. Cet. II; Jakarta: Rajawali Press, 2012

Fakih, Mansoer. et. al. Membincang Feminisme: Diskursus Gender Perspektif Islam. Surabaya: Risalah Gusti, 1996.

Menggeser Konsepsi Gender dan Tranformasi Sosial. Yogyakarta: Pustaka Pelajar, 1996

Fuad, Mahsun. Hukum Islam Indonesia Dari Nalar Partisipatoris Hingga Emansipatoris. Cet. I; Yogyakarta: LKiS, 2005.

Hanafi, Muchlis M. dkk., Hukum, Keadilan dan Hak Asasi Manusia: Tafsir al-Qur'an Tematik Jakarta: Lajnah Pentahshihan Mushaf al-Qur'an, 2010

Hasan, Sandi Suwardi. Pengantar Cultural Studies: Sejarah, Pendekatan Konseprual dan Isu Menuju Studi Budaya Kapitalisme Lanjut. Cet. I; Jogjakarta: Ar-Ruzz Media, 2011.

Husaini, Adian "Kesetaraan Gender: Konsep dan Dampaknya Terhadap Islam," ISLAMIA 2, no. 5 (2012), 14

Ibn 'Utsaimîn, Al-Qaul al-Mufìd 'Alâ al-Kitâb al-Tauhîd Riyadh: Dâr Ibn al-Jauzî, 1424

ibn Manẓūr al-Anșārī, Muhammad ibn Mukrim ibn 'Alī Abu al-Faḍl Jāmal al-Dīn. Lisan al-'Arab, vol. IV t.t: Dar al-Ma'arif, 1979

Ibrāhīm Husa'in al-Syāżalī, Sayyid Quțub. F̄̄ Zilāl al-Qur'ān, Jilid II Cet. XVII. Qairoh: Dār al-Syuruq, 1412 
John M. Echos, dkk., Kamus Inggris Indonesia (Cet. XXV. Jakarta: PT Gramedia Pustaka Utama, 2003

Ka'bah, Rifyal. Politik dan Hukum dalam Alquran Khairul Bayan: Jakarta, 2005

Kadarusman, Agama, Relasi Gender dan Feminisme Yogyakarta: Kreasi Wacana, 2005

Kau, Sufyan A. P. dan Zulkarnain Sulaiman. Fikih Kontemporer: Isu-Isu Gender Menghadirkan Teks Tandingan. Cet. I; Gorontalo: Sultan Amai Press, 2011.

Maloko, M. Thahir. Dinamika Hukum dalam Perkawinan Cet. I; Makassar: Alauddin University Press, 2012

Mas'udi, Masdar Farid. Hak-hak Reproduksi Perempuan: Dialog Fiqih Pemberdayaan. Bandung: Mizan, 1997

Megawangi, Ratna. Membiarkan Berbeda? Bandung: Mizan, 1999

Muhammad, KH. Husein. Figh Perempuan: Refleksi Kiai atas Wacana Agama dan Gender Cet. VI; Yogyakarta: LKiS, 2012

Mulia, Musdah. Muslimah Sejati: Menempuh Jalan Islam Meraih Ridha Ilahi Cet. I; Bandung: Penerbit Marja, 2011

Muslih,Mohammad.Bangunan Wacana Gender Ponorogo: CIOS, 2007

Nugroho, Riant. Gender dan Strategi Pengarus-Utamaan di Indonesia. Cet. I; Yogyakarta: Pustaka Pelajar, 2011.

Nugroho, Riantm. Gender dan Strategi Pengarus-Utamaan di Indonesia Cet. I; Yogyakarta: Pustaka Pelajar, 2011

Nuruddin Amiur dan Azhari Akmal Tarigan, Hukum Perdata Islam di Indonesia: Studi Kritis Perkembangan Hukum Islam dari Fikih, UU No 1/1974 sampai KHI Cet. IV; Jakarta: Prenadamedia Group, 2012

Qurrotul Ainiyah, Keadilan gender dalam Islam: Konvensi PBB dalam Perspektif Mazhab Syafi'i. Malang: Kelompok Lintas Publishing, 2015.

Rofiq, Ahmad. Hukum Islam di Indonesia, Edisi I. Cet. I; Jakarta: Raja Grafindo Persada, 1995.

Sabiq, Sayyid. Fiqhu as-Sunnah, Jilid. III. Cet. XXI; Kairo Mesir: Dar al-Fath Li alI'lami al-Arabiy, $1420 \mathrm{H} / 1999 \mathrm{M}$.

Sastrawaty, Nila. Laki-laki dan Perempuan Identitas yang Berbeda: Analisis Gender dan Politik Perspektif Post-Feminisme. Cet. I; Makassar: Alauddin University Press, 2013.

Subhan, Zaituna. Rekonstruksi Pemahaman Gender dalam Islam: Agenda SosioKultural dan Politik Peran Perempuan Jakarta: El-Kahfi, 2002

Sugono, Dendy. Kamus Bahasa Indonesia Jakarta: Pusat Bahasa, 2008

Umar, Nasaruddin . Argumentasi Kesetaraan Jender Perspektif al-Qur'an Cet. II; Jakarta: Paramadina, 2001

Wison, H.T. Sex and Gender, Making Cultural Sense of Civilization Lieden: E.J. Brill, 1989 